\title{
STUDY OF PHYTOCHEMICAL AND ANTIMICROBIAL ACTIVITIES OF WALTHERIA INDICA
}

\author{
Musa Y. ${ }^{1}$, Musah M. ${ }^{2 *}$, Yerima H. $^{3}$, and Erena N.B. ${ }^{4}$ \\ $* 1,2,3$ Department of Chemistry, Niger State College of Education, Minna \\ ${ }^{4}$ Department of Integrated Science, Niger State College of Education, Minna
}

*Corresponding Author: -

Email:mkwagana@gmail.com; yusufauna39@yahoo.com

\begin{abstract}
: -
Waltheria indica is used in Nigeria and other parts of the world as traditional medicine for the treatment of several ailments such as skin disease, impotence, malaria, typhoid fever, epilepsy infertility, aches, pains, syphilis, pile, cough, sore throat, gonorrhea and leprosy among others. The extracts of this plant: Aqueous, chloroform and methanolic extract were subjected to both phytochemical and antimicrobial screening. The result of the phytochemical screening showed the occurrence of Flavonoids, Anthraquinones, Saponins, Tannins, Terpenes, Cardiac glycosides and Carbohydrate. But absence of free anthraquinone and phlobatanines. The Antimicrobial activity of the extracts using Agar plate-hole, Nutrient broth and Agar diffusion method. It was found that the plant extracts from both methanol and chloroform were not able to exhibit any reasonable activity while Aqueous extract showed reasonable activity with Escherielia coli and Staphyhococcusaureus. These finding, however, support the traditional use of the Waltheriaindica for the treatment of the above-mentioned diseases. This is because Aqueous extract is the only extract that show inhibitory effect and similarly the traditional healers use water for their extraction.
\end{abstract}

Keywords: Waltheriaindica, Flavonoids, Anthraquinones, Saponins, Tannins, Terpenes

\section{(c) $(\$)$}




\section{INTRODUCTION}

Plants extract have been used for the treatments of common infectious diseases even before the availability of synthetic drugs in most country of the world [1,2]. In developing nation, the use of plants for their primary health care is still in use [3].

Some plants contain active substances for the cure of diseases in humans [4], [5]. In Togo and South Africa, extracts of plant of the family Combretaceae are highly recommended for their antifungal activity [6], [7]. In Senegal, Côte d'Ivoire and sub-Sahelian Africa, it has been shown that certain plants such as Parkiabiglobosa(Jacq) are hypotensive [8], antidiarrheal [9] or analgesic and anti-inflammatory [7]. Knowledge of medicinal plants sometimes means the only therapeutic resources of some communities and ethnic groups [10]. In Nigeria, traditional healers are still consulted as a first choice due to the fact that traditional medicine blends readly into the socio-cultural life of the people [11]. Various plant organs such as leaves, flowers, bark roots or whole plant are used in traditional treatment of conditions such as bronchitis, hypertension, diarrhea, abdominal pain [12].

Waltheria indica L. or sleepy morning, also known as velvet leaf, marsh-mallow, monkey bush, boater bush, leather coat, buff coat [13] and locally, hankufah in Hausa, kafafi in Fulfulde, korikodi in Yaruba and efu-abe in Nupe [14], [15], belong to the family Sterculiaceae. It is found throughout the tropics and warmer subtropics. It apparently naturalized in Hawaii soon after the arrival of nonnative colonists [16] The species is native to the New World where it occurs from Florida and Texas to Brazil. The plant has been used as an infusion or decoction where febrifugal, purgative, emollient, tonic, analgesic and astringent action is sought [13]. In the Turks and Caicos Islands, it is used to make herb tea. The plant produces a fiber that was formerly used for making cords, sacking, padding and sandals. Stems are used as a chew stick; extracts of the plant are used for treatment of cough and curing female sterility. In Hawaii, the root is chewed to relieve sore throat as well as treatment of gonorrhea and leprosy in humans. Stems are used as a chew stick while its extracts are used as an eye bath and a remedy for hemoptysis in Panama, treatment of cough and a cure for female sterility [16]. In Northern Nigeria, the plant is used by the Hausas for the treatment of skin diseases, impotence, and infertility, as an aphrodisiac, and as children's medicine at birth and during teething [17]. In the Fulani community, the aqueous extract of the root is used in relieving aches and pains during the 'Sharo' festival. Among the Yoruba, the aqueous extract of the root and stem is used in treating syphilis, internal haemorrhage, and as a restorative during the labours of harvesting [17]. From literature search, there is a lack of scientific proof to support the medicinal importance of this plant in the treatment of diarrhea, dysentery, pulmonary troubles and venereal diseases. Hence, this study was designed to investigate the qualitative phytochemical components and antimicrobial activities of $W$. indica plant extracts.

\section{MATERIALS AND METHODS Collection, Identification, Authentication and Drying of the Sample}

The fresh leaves, stems and roots of Waltheria indica were collected on a piece of land located at Niger State College of Education, Minna, Nigeria. They were collected in large quantity and were air dried under room temperature to retain its nutrients/constituents and pounded afterwards using pestle and mortar to increase surface area. the plant was identified and authenticated by Dr. Mann Abdullahi of Chemistry Department, Federal University of Technology Minna and Dr. Jonathan N. Gana of Biology Department, Niger State College of Education Minna.

\section{Extraction of Bio-active Constituents}

Cold aqueous maceration method was used to obtain the plant extracts. This was achieved by blending the air-dried powdered plant sample into $500 \mathrm{~cm}^{3}$ of distilled water. The blended suspension was then filtered. The plant was also extracted with chloroform and methanol to get the chloroform and methanolic extract.

The three extracts were evaporated to dryness on a water bath, cooled and transferred into three containers labeled and kept for phytochemical and antimicrobial test.

\section{Phytochemical Screening}

The aqueous, chloroform and methanolic extracts were subjected to phytochemical screening/test to determine their chemical constituents using standard methods as described by [18,3]. Phytochemical test for carbohydrates, reducing sugar, combined reducing sugar, alkaloids, anthroquinones, flavonoids, saponins, cardiac glycosides, digitalis glycosides, tanins, phlobatannins and terpenes were conducted.

\section{Media used and preparation}

Nutrient broth and nutrient ager were prepared based of manufacturers specification

\section{Antimicrobial screening}

The antimicrobial screening of the extracts was done in the microbiology laboratory of the Federal University of Technology, Minna.

\section{Bacterial Culture}

Five (5) Bacterial isolates Escherichia coli, Salmonella typhi, Pseudomonas aeruginosa, Bacillus subtilisand Staphylococcus aureuswere collected from the Microbiology Departmental Laboratory of the Federal University of Technology, Minna, Nigeria. All the cultures were checked for purity and maintained in nutrient birth slants. 
Culturing of the Bacterial isolates

Using sterile wire loop, the five isolates Escherichia coli, Salmonella typhi, Pseudomonas aeruginosa, Bacillus subtilis and Staphylococcus aureus were inoculated into $9.0 \mathrm{ml}$ of Nutrient broth each in five test tubes and labeled E.C, S. typi, P.a, B.s and S.a respectively to form five cultures. These five cultures were then incubated at $37^{\circ} \mathrm{C}$ for some hours.

\section{Reconstitution of the Extracts}

The extracts of the plant (Waltheria indica) were three, namely Aqueous, chloroform and methanol extract which were labelled 1, 2 and 3 respectively. Each of the three extracts were reconstituted with $1 \mathrm{ml}$ of distilled water and $4 \mathrm{ml}$ of D.M.S.O (Dimethyl sulfoxide) into three sample bottles containing $0.8 \mathrm{~g}, 1.0 \mathrm{~g}$ and $1.2 \mathrm{~g}$ respectively (i.e. three sample bottles labeled $0.8,1.0$ and 1.2 for each extract to make up in all 9 sample bottles). Another one sample bottle was used to prepare the "control" by weighing $0.1 \mathrm{~g}$ of ampiclox in $\mathrm{ml}$ of Aqua.

\section{Screening of extracts for Antimicrobial Activity}

Agar diffusion method was used. In this method, sterile Nutrient Agar (NA) plates were dried in the oven to dehydrate the water of condensation. The dried Nutrient Agar (NA) plates used were about fifteen (15). A 4mm sterile cork borer was used to bore three wells into each of the dried Agar plates. The fifteen (15) bored Nutrient Agar plates were divided into five (5) sets, (i.e. each set contains three (3) plates). The three (3) plates of each set were labeled 1, 2 and 3, (i.e. to signify the plates in which the first, second and third extracts will be dispensed).

The first plate of each of the five sets labeled " 1 " had a well in the centre of the diameter in addition to the three well earlier bored. (i.e. to make four wells in the first plate). The well at the centre stands for control and labeled " $\mathrm{C}$ " at the bottom of the plate where it was located. The remaining three wells of each of the fifteen Nutrient Agar plates were labeled 0.8, 1.0 and 1.2 respectively at the bottom of the plate where the wells where located. Each of the three (3) plates in the five sets were also labeled E.C, S.typ, P.a, B.S and S.a respectively. (i.e. to signify the organism that should be used to inoculate the surface of each set).

\section{Determination of inhibitory effects of the plant extracts on the Bacterial isolates}

Using five (5) sterile cotton swab sticks labeled E.C, S.typ, P.a, B.S, and S.a respectively, the surface of each of the Nutrient Agar plates in the five sets where inoculated with the cultured bacterial isolates in accordance to the label of the "bacterial name" on them.

Using Nine (9) syringes and needles in a set of three labeled 0.8, 1.0 and 1.2, another three labeled 0.8, 1.0 and 1.2 and the last three labeled $0.8,1.0$ and 1.2, the reconstituted extracts were aseptically dispensed into the wells of each of the three Nutrient Agar plates of the five sets in accordance to the labels at the bottom of the plates, syringe and the sample bottles. The plates were allowed to stand on the work bench for 30 minutes then wrapped in aluminium foil and incubated at $37^{\circ} \mathrm{C}$ for period of 18 to 24 hours in an incubator. Afterward, the plates were observed for any clear zone of inhibition. The observation of zone of inhibition was an indication that the plant extracts were able to hamper the growth of the organisms (i.e. there is presence of antimicrobial activity). The inhibitory actions of the extracts on the microbes were observed and tabulated.

\section{RESULTS AND DISCUSSION}

\section{Phytochemical Screening Result}

The phytochemical screening of the extracts revealed the presence of some chemical constituents which are shown in the table below: 
Table 1: Results of Phytochemical screening of the extracts of Waltheriaindica.

\begin{tabular}{|c|c|c|c|c|c|c|}
\hline $\mathrm{S} / \mathrm{N}$ & $\begin{array}{l}\text { Chemical } \\
\text { constituents }\end{array}$ & Test & Observation & Methanol & Chloroform & Water \\
\hline 1. & Alkaloids & Nil & Nil & $\mathrm{Nil}$ & Nil & Nil \\
\hline \multirow[t]{4}{*}{2.} & Carbohydrates & Molisch's & Dull violet & & & \\
\hline & General test & & $\begin{array}{l}\text { colouration } \\
\text { at interface } \\
\text { of ring layer }\end{array}$ & + & +++ & ++ \\
\hline & $\begin{array}{l}\text { * Reducing } \\
\text { sugar }\end{array}$ & Felling's & Red ppt & ++ & + & - \\
\hline & $\begin{array}{l}\text { * Combined } \\
\text { reducing sugar }\end{array}$ & Felling's & Red ppt & ++ & - & +++ \\
\hline \multirow[t]{3}{*}{$\begin{array}{l}3 . \\
4 .\end{array}$} & $\begin{array}{l}\text { Flavonoid } \\
\text { Anthraquinone }\end{array}$ & $\mathrm{NaOH} / \mathrm{NH}_{3}$ & Yellow ppt & - & +++ & +++ \\
\hline & $\begin{array}{l}* \quad \text { Free } \\
\text { anthraquinone } \\
* \text { Combined } \\
\text { anthraquinone }\end{array}$ & $\mathrm{C}_{6} \mathrm{H}_{6} / \mathrm{NH}_{3}$ & $\begin{array}{l}\text { Violet } \\
\text { colour in } \\
\text { ammonical } \\
\text { layer }\end{array}$ & - & - & - \\
\hline & $\begin{array}{l}\text { * Combined } \\
\text { anthraquinone }\end{array}$ & $\begin{array}{l}\mathrm{H}_{2} \mathrm{SO}_{4}+ \\
\mathrm{C}_{6} \mathrm{H}_{6} / \mathrm{NH}_{3}\end{array}$ & $\begin{array}{l}\text { Violet } \\
\text { colouration } \\
\text { in } \\
\text { ammonical } \\
\text { layer }\end{array}$ & + & - & ++ \\
\hline 5. & Saponins & $\begin{array}{l}\text { Frothing or } \\
\text { foaming }\end{array}$ & $\begin{array}{l}\text { Persistence } \\
\text { of foam or } \\
\text { froth. }\end{array}$ & + & +++ & +++ \\
\hline 6. & Tannins & $\mathrm{Fecl}_{3}$ & $\begin{array}{l}\text { Dark-green } \\
\text { colouration } \\
\text { or blueblack }\end{array}$ & ++ & +++ & +++ \\
\hline 7. & Terpenes & $\begin{array}{l}\text { Lieberman } \\
\text { Burchard }\end{array}$ & $\begin{array}{l}\text { Red/violet } \\
\text { colouration }\end{array}$ & + & - & + \\
\hline 8. & Phlobatannins & $\begin{array}{l}\text { Filterate } \\
+\mathrm{Hcl}\end{array}$ & $\begin{array}{l}\text { Faded } \\
\text { yellow } \\
\text { colouration }\end{array}$ & - & - & - \\
\hline \multirow[t]{2}{*}{9.} & $\begin{array}{l}\text { Cardiac } \\
\text { glycosides } \\
* \quad \text { Steroidal } \\
\text { Nucleus }\end{array}$ & Salkowskii's & $\begin{array}{l}\text { Reddish } \\
\text { brown ring } \\
\text { colour at } \\
\text { interface }\end{array}$ & + & - & +++ \\
\hline & $\begin{array}{l}* \quad \text { Digitallis } \\
\text { glycosides }\end{array}$ & & $\begin{array}{l}\text { Reddish } \\
\text { brown ring }\end{array}$ & +++ & +++ & +++ \\
\hline
\end{tabular}

Keys: $+++=$ Highly present, $++=$ Moderately present, $+=$ Minimally present, $-=$ Not present Antimicrobial Screening Activity of the Plant Extracts

Table 2: Diameter of zone of inhibition of the plant extracts in millimeter (MM).

\begin{tabular}{|c|c|c|c|c|c|c|c|c|c|c|c|c|}
\hline \multirow[b]{2}{*}{$\mathrm{S} / \mathrm{N}$} & \multirow[b]{2}{*}{ Organism } & Extracts & \multicolumn{3}{|l|}{1} & \multicolumn{3}{|l|}{2} & \multicolumn{3}{|l|}{3} & \multirow{2}{*}{$\begin{array}{l}\text { C } \\
0.1\end{array}$} \\
\hline & & $\operatorname{Mic}(\mathrm{g} / 5 \mathrm{ml})$ & 0.8 & 1.0 & 1.2 & 0.8 & 1.0 & 1.2 & 0.8 & 1.0 & 1.2 & \\
\hline 1 & E. Coli & & 31 & - & 21 & 11 & 8 & - & - & - & - & - \\
\hline 2 & S. typi & Diameter of & - & - & - & - & - & - & - & - & - & 18 \\
\hline 3 & P. aeruginosa & $\begin{array}{l}\text { zone of } \\
\text { inhibition }\end{array} \Rightarrow$ & - & - & - & - & - & - & - & - & - & 18 \\
\hline 4 & B. Subtilis & & - & - & - & - & - & - & - & - & - & 31 \\
\hline 5 & S. aureus & & 16.5 & - & 16.5 & - & - & - & - & - & - & 16 \\
\hline
\end{tabular}

Keys: $\mathrm{C}=$ Control (Ampiclox) $0.1 \mathrm{~g} / 5 \mathrm{ml}$, - = No inhibition, 1 =Aqeous Extract, $2=$ Chloroform Extract, $3=$ Methanol Extract, Diameter of zone of inhibition is express in millimeter (MM). Mic = Minimum inhibitory concentration of the extracts $10.8 \mathrm{~g} / 5 \mathrm{ml})$. 
Table 3: Activity of plant extract (Waltheriaindica) on selected microbes.

\begin{tabular}{lllll}
\hline Bacteria & Control(C) & Aqeous Extract & $\begin{array}{l}\text { Chloroform } \\
\text { Extract }\end{array}$ & $\begin{array}{l}\text { Methanol } \\
\text { Extract }\end{array}$ \\
\hline Escherichia coli & No Activity & Active & Partial activity & No activity \\
Salmonella typhi & Active & No Activity & No activity & No activity \\
Pseudomonas aeruginosa & Active & No Activity & No activity & No activity \\
Bacillus subtilis & Active & No Activity & No activity & No activity \\
Staphylococcus aureus & Active & Active & No activity & No activity \\
\hline
\end{tabular}

The phytochemical screening of the three extracts are shown in table 1 . The phytochemical analysis revealed the presence of medicinally active constituents; flavonoids, anthraquinones, saponins, tannins, texpenes, cardiac glycosides as well as presence of nutritional constituents like carbohydrates. The active constituents were abundant in the aqueous and methanolic extract. Carbohydrates like reducing sugars were moderately present in the methanolic extract, while it is minimally present in chloroform extract and not detected in aqueous extract. Combine reducing sugar were moderately and highly present in methanolic and aqueous extract respectively, and not detected in chloroform extract. Flavonoids was highly detected in both chloroform and aqueous extract while it is absent in methanolic extract. Phlobatannins and free anthraquinones were not detected in all the three extracts. Besides, combined anthraquinones were minimally and moderately present in methanolic and aqueous extract respectively, but not detected in chloroform extract. Tannins and saponins were moderately present in methanolic extract, highly present in both chloroform and aqueous extract.

The presence of tannins, saponins and alkaloids in the extracts explains the activities of the plant against the disease caused by the test organisms, since the phytochemicals have been identified as highly antiviral and antibacterial agents [19]. Also, terpenoids, alkaloids and flavonoids have been found in vitro to have antimicrobial properties [20]. Although, alkaloids were not tested in these extracts due to unavailability of the regents used in testing it. Tannins and flavonoids have also been reported to be responsible for antidiarrheal activity [21] Terpenes were minimally present in both methanolic and aqueous extract, but not detected in the chloroform extract, for cardiac glycosides, the digitalis glycosides were highly present in all the three extracts, while steroidal nucleus is highly present in aqueous extract, moderately present in methanolic extract and not detected in chloroform extract.

In general, the distribution of these phytochemicals in the three solvents was dependent upon their polarities and those of the extracting solvents [19] According to [22], Alkaloids, anthraquinones, cardiac glycosides, phenols, tannins, and saponins are known to have antibacterial activity against pathogens and could be used traditionally for therapeutic purpose. However, this phytochemical finding could explain the role of Waltheria indica as a good antimicrobial agent, hence the justification of its local use in the treatment of many diseases.

The antimicrobial screening activities of the plant extract were stated in table 2 , and table 3 . Considering the data analysis in table 2 and 3, the aqueous extract (1) and chloroform extract (2) had some active inhibitory effects on Escherichia coli, while the control (c) had no any effect of activity.

Although the activity of chloroform extract (2) on Escherichia Coli was partial, while the methanol extract (3) had no activity on it. All the three extracts (1), (2) and (3) had no active inhibitory effect on Salmonella typhi, Pseudomonas aeruginosa, and Bacillus subtilis, while the control (c) had effect of activity on the three microbes. Among all the three extracts, only the aqueous extract (1) and its control (c) had active inhibitory effect on Staphylococcus aureus.

However, the result of the antimicrobial screening supports the assertion of Gunners [23] who reported that different solvent extracts of some plants may exhibit different pharmacological properties against the same species of microorganisms. This is why there was activity with some extracts as well as non in the other. Similarly to the phytochemical screening of this research work, [24] noted that the variations in the phytochemical components of plant extracts is aclear point to proof that the botanically active compounds (phytochemicals) in the media largely depend on the type of solvent and probably the extraction method(s) used. Traditional healers are known to use primarily water as solvent of extraction.

\section{Conclusion}

The findings of this research reveals the presence of phytochemicals which support the basis for traditional use of Waltheriaindica extract for treating skin disease, impotence, malaria, typhoid fever, epilepsy, infertility, aches, pains, syphilis, pile, cough, sore throat, gonorrhea and leprosy. The plant extract has shown propensity of offering therapeutic actions against various infections especially those resulting from Escherichia Coli and Staphylococcus aureu

\section{Acknowledgement}

The authors wishes to acknowledge the support of laboratory technologist of the department of Chemistry, College of Education, Minna and department of Microbiology, Federal University of Technology, Minna for their assistance.

\section{References}

[1].D.M. Eisenberge, R.C. Kesler, C. Foster, F.E. Norlock, D.R. Calkinsand and T.L. Delbanco (1993). Unconventional Medicine in the United States: Prevalence, costs and Patterns of use. N. Engl. J. Med., 328: 246-252.

[2].K. Hostettmann, A. Marston, K. Ndojoko and J. Wolfender (2000). The potential of Africa Plants as a source of drug. In: Curr. Organic Chem., 4: 973-1010 
[3].M. Kone, K. Ouattara, A. Ghahoue. and A. Coulibaly. (2013). Study ethnopharmacological and phytochemical screening of some plants involved in the treatment of abdominal infections in the department of kouto. Sch. J. App. Med. Sci., 1(2):56-61

[4].O. O. Olajuyigbe, A.E. Babalola and A.J. Afolayan (2011) antibacterial and phytochemical screening of crude ethanolic extracts of WaltheriaindicaLinn. African Journal of Microbiology Research, 5: 3760-3764.

[5].A.A. Silva Junior, V.J. Vizotto, E. Giongi, S.G. Macedo and L.F. Marques (1994). Plantas medicinais, caracterização e cultivo.EPAGRI.Bol. Técnico Florianópolis, pp. 68: 1-71.

[6].K. Batawila, K. Kakou, K. Koumaglo, M. Gbeassor, B. De Foucault, P. Bouchet and K. Akpagana (2005). Antifungal activities of five combretaceae used in Togolese traditional medicine. Fitoterapia, 76: 264-268

[7].F. Kouadio, C. Kanko, M. Juge, N. Grimaux, A. Jean, Y.T. N'guessan and J.Y. Petit (2000). Analgesic and antiinflammatory activities of an extracts from Parkiabiglobosa used in traditional medicine in Ivory Coast. Phytotherapy Research, 14:635-637.

[8].M. Assane, R. Baba Moussa, E. Bassene and A.Sere (1993). Anti hypertensive action of Parkiabiglobosa (kacq) Benth seeds in the rat. Dakar-Medicine. 38:49-54;

[9].A. Y. Tijani, S.E. Okhale, T.A. Salawu H.O. Onigbanjo, L.A. Obianodo, J.A. Akingbasote, O.A. Salawu, J.I. Okogun, F.O. Kunle and N. Emeje (2009). Anti diarrhoeal and antibacterial properties of crude aqueous stem bark extract and fractions Parkia biglobosa (Jacq). African Journal of pharmacy and pharmacology, 3:347-353.

[10]. L.C. Di Stasi (1996). Arte, ciência e magia. In LC Di Stasi, CA Hiruma-Lima (eds), PlantasMedicinais: Arte e Ciência, São Paulo, pp. 15-21

[11]. S.L. Kela and J.H. Kufeji (1995). Screening of some Nigerian plants for bactericidal activity. J. Microbiol., 10: 1822.

[12]. H.A. Attia and M.M. Samar (2004). Antidiarrhoeal activity of some Egyptian medicinal plant extracts. Journal of Ethnopharmacology, 92:302-309.

[13]. H.M. Burkill (2000). The useful plants of West Tropical Africa. Royal Botanic Gardens, Kew, UK, p. 686.

[14]. M.J. Hutchinson and J.M. Dalziel (1958). Flora of West Tropical Africa. Crow Agent for oversea Government and Administration, Mill Bank, London. 319

[15]. F.R. Irvine, (1961). Woody plants of Ghana, Oxford University Press, London. P. 185.

[16]. W. L. Wagner, D.R. Herbst and S.H. Sohmer (1990). Manual of the flowering plants of Hawai'i.vols., Bishop Museum Special Publication 83. Honolulu: University of Hawaii Press and Bishop Museum Press, p.1280.

[17]. Z. Mohammed, M. Shok, N. Ilyas, K.Y. Musa and A.H. Yaro (2007). Analgesic activity of Waltheria indica. European Journal of Scientific Research, 16(1):1-6.

[18]. J.B. Harborne (1984). Phytochemical Methods.2nd ed. Chapman and Hall, London, Pp19-25

[19]. M.A. Tijjani, F.I. Abdulrahman and U.K. Sandabe (2011). Chemical Composition and Anti-nociceptive Effects of the Leaf Extract of Vitexdoniana Sweet. Journal of Chemical Society of Nigeria, 36(1): 213-219

[20]. M.M. Cowan (1999). Plant products as anti-microbial activity. Clinical Microbiology Review, 4; 12:564-582.

[21]. B. J. Okoli (2009). Phytochemical Analysis of Chrysorphyllumalbidumseed and Milicia excels Leaves. Int. J. Sci., 2(2): 221-227

[22]. H. Usman and J.C. Osiji (2007). Phytochemical and in vitro antimicrobial assay of the leaf extract of Newbouldialeavis Afr. J. Trad. CAM, 4(4): 476-480

[23]. B. Gunner (1991). McGraw Hill encyclopedia of science and technology vol 1;8th edition.:205.

[24]. M.M. Ndamitso, M. Musah, Z. Mohammed-Hadi, S. Idris, O.J. Tijani, E.Y. Shaba and A. Umar, (2013). Analysis of Phytochemical content and Antibacterial Activity of Tapinanthus dodoneifolius Extracts. Researcher; 5(5):5459. 